\title{
SZUBURBANIZÁCIÓ ÉS VÁLASZTÁSI FÖLDRAJZ: ÁTALAKULÓ PÁRTVÁLASZTÁS BUDAPEST TÉRSÉGÉBEN
}

\author{
(Suburbanisation and Electoral Geography: \\ Changing Party Preferences in the Area of Budapest)
}

\section{JANKÓ FERENC - KOMORNOKI MIHÁLY}

\begin{abstract}
Kulcsszavak:
szuburbanizáció választásiföldrajz Budapest agglomeráció Pest megye

Tanulmányunkban Budapest térségében statisztikai módszereket felhasználva vizsgáltuk meg az egyes nyugati példákban tapasztalható központ-bal, szuburbia-jobb pártpreferencia-modell érvényességét, amelyet több területi és módszertani közelités után elvetettünk. Az eltérö hazai fejlödés oka abban lehet, hogy a magyarországi jobb és bal oldali pártok, skülönösen az SZDSZ, a nyugati demokráciák pártjaitól eltérõ szavazóbázissal rendelkeznek, ami a hazai párttörténelemben a rövid, ám viharos rendszerváltás utáni időszakban gyökeredzik. Másfelöl arra is utalást kaptunk, hogy a magyar szuburbanizációs folyamattal jelenleg az egykori rurális terek, az agglomerációs települések erốs átalakitása folyik, azaz a szuburbán zónákban nem érvényesül a szomszédsági hatás, hanem a kiköltözök a magukkal hozott politikai mintákat örzik meg. Lehetséges azonban, hogy e tendencia idővel átbillen, s a pártrendszer stabilizálódảsa, a párt-ideológiai paletta letisztulása esetén Magyarországon is kialakul a helyi társadalmak politikai szembenállása a központi város és környezete között.
\end{abstract}

\section{Bevezetés}

A budapesti szuburbanizáció már számos folyóiratcikk, könyv témája volt, lakossági, gazdasági vetületben egyaránt, ennek révén meglehetősen jól ismerjük már dinamikáját, mozgatórugóit, területi sajátosságait, a résztvevők összetételét, hatását a közlekedési rendszerekre, a természeti környezetre, területfelhasználásra. Némely vetületben az érintett településekre, ill. a helyi társadalomra gyakorolt hatásokat is bemutatták már, azonban konkrétan a szuburbanizációban részt vevỏ települések választói magatartásának esetleges módosulása még igen kevéssé vizsgált terület hazánkban. Számos tanulmánykötet, politikai atlasz elemzi Magyarország választási földrajzi tagolódását, és sokan rámutattak már a pártok területi beágyazódásának viszonylagos stabilitására (pl. Kovács Z. 2000; 2001; Hubai 2001; legújabban Mészáros et al. 2007).

A szuburbanizációs folyamatok politikai földrajzi következményei egyes résztémákban jobban ismertek, hiszen igen fontos problémakör a központi település, jelen esetben Budapest és a szuburbán települések közötti közigazgatás-szervezési viszony, s ezen belül a városrégió finanszírozása (Dövényi-Kovács $Z$. 1999; Perger 1999; Kovács $R$. 2007). Egészen pontosan már választás-földrajzi kérdés az, amely szintén ismert a hazai kutatók, söt a közvélemény egy része elött is -, hogy az 1990 óta változatlan beosztású választókerületekben a migrációs és a demográfiai 
folyamatok területi sajátosságai miatt a politikai képviseletben egyenlötlenségek alakultak ki. A rendszerváltozás óta a képviselet szempontjából meglehetősen aránytalanná vált az eredetileg sem teljesen arányos választókerületi beosztás, mind a területi, mind az egyéni mandátumok számát tekintve Budapest felül-, Pest megye pedig alulreprezentált lett. Nem véletlenül, hiszen a választásra jogosultak száma 1990 és 2006 között Budapesten 1 millió 518 ezerröl 1 millió 379 ezerre csökkent, miközben Pest megyében 707 ezerröl 900 ezer fölé nőtt számuk, ám a két területen kiosztható mandátumok száma változatlan maradt.

Tanulmányunk tárgya a fent már megemlített konfliktushoz kötődik. A szuburbán településeken az „őslakosok” és az újonnan érkezők között ellentét merülhet fel, a „térért folytatott harc" megnyilvánulhat a településen belüli szegregációs problémákban, de politikai konfliktusokban is, hiszen az is elöfordulhat, hogy egy tősgyökeres és egy beköltöző vetélkedik a polgármesteri székért, vagy a képviselöi helyért, azaz a helyi elit is átalakul (Dövényi-Kovács Z. 1999). Ennek fẻnyében nem jelentéktelen kérdés, hogy vajon megváltozott-e, $s$ ha igen, hogyan a politikai pártpreferencia a budapesti agglomerációban, és ez mennyiben hozható összefüggésbe a települések szuburbanizációban való részvételével, illetve annak mértékével. Tanulmányunk választásföldrajzi kérdése túlmutat a téma tudományos érdekességén, hiszen a városrégió politikai arculatának alakulása, annak kormányzása szempontjából nem sokadrangú probléma. Hiszen jól ismert a múltból, hogy az egyébként inkább konzervatív beállítottságú és vezetésú fơváros sokáig azért ódzkodott NagyBudapest létrehozásától, mert a többségében munkások által lakott elővárosok és falvak integrálásával felborultak volna az addigi politikai erőviszonyok (Perger 1999).

Közismert, hogy fóvárosunk politikai irányultsága baloldali és liberális, és ezért az utóbbi választások kulcsterülete is volt egyben. Ebböl kiindulva vizsgálataink legelején azt vártuk, hogy az erósebben szuburbanizálódó, illetve a városiasabb településeken ezek a pártok növelték támogatottságukat, de feltételeztük azt is, hogy esetleg a szintén városi szavazóbázisú MIÉP is növelte erejét az agglomerációban. Vagyis azt reméltük, hogy a szuburbanizáció foka, minösége és a pártszimpátia átalakulása, és annak markáns vagy kevésbé markáns volta között összefüggés mutatható ki.

A témához kapcsolódó első hazai tanulmányok tudomásunk szerint Horváth (2004; 2005) tollából származnak, aki a szuburbanizációnak az Európai Parlamenti választás eredményeire gyakorolt hatását vizsgálta az agglomerációban, egyszerủ módszerekre alapozva, a népességnövekedés, a végzettség, illetve a választási részvétel és a különbözỏ pártok eredménye közötti összefüggést kutatva. Kimutatása szerint a jobb oldali pártok a nagyobb népességnövekményủ és magasabb diplomás arányú szektorokban, ill. településeken jobb eredményeket értek el, ami hipotézisünkkel némileg ellentétes következtetés.

Természetesen figyelembe kell venni, hogy a fôváros körüli települések népességi növekménye nem csak a budapestiek kiköltözéséből származik, arányuk kb. $60 \%$. Másfelöl az is közismert, hogy területileg differenciált, szektorálisan eltéró intenzitású, jellegủ folyamat, azaz legintenzívebb a budai oldalon, a nyugati és az északi szektorokban, míg a délkeleti részekbe kevésbé módos rétegek költöznek inkább (Beluszky 1999; Dövényi-Kovács Z. 1999). 
Jankó Ferenc - Komornoki Mihály : Szuburbanizáció és választási földrajz: Átalakuló pártválasztás Budapest térségében.

Tér és Társadalom 22. évf. 2008/4. 115-134. p.

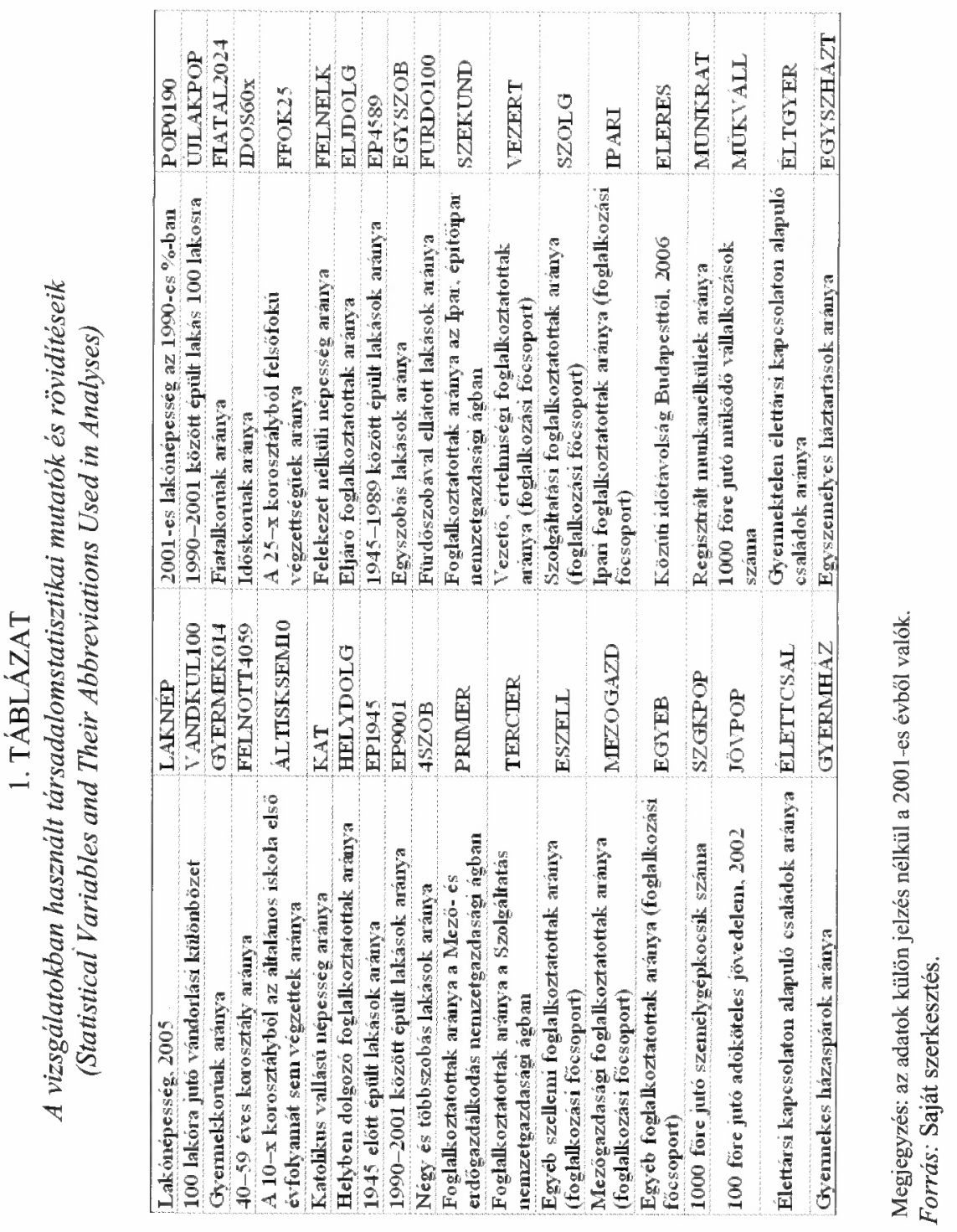




\section{Vizsgálati terület, adatok}

Vizsgálatainkhoz szükséges adatainkat Pest megye településeire gyüjtöttük, s a hatályos lehatárolás szerinti agglomerációt és a maradék Pest megyei településeket különítettük el egy csoportba a vizsgálatok egyes eseteiben. A vizsgált időintervallumban bekövetkezett közigazgatás-szervezési változások miatt az újabb adatokat is az 1990-es időpontban fennállt településállományra konvertáltuk. ${ }^{1}$

Vizsgálatainkhoz egyfelöl településsoros, pártlistás választási eredményeket használtunk fel az 1990 és 2006 közötti öt választási időpontra. Ahhoz, hogy az egyes pártokra adott szavazatok, illetve szavazati arányok idöben is összehasonlíthatók legyenek, $\mathrm{s}$ az egymással való összevetés is még inkább biztosítva legyen, a listás szavazatarányokat az országos átlag százalékában fejeztük ki. Ily módon az adatsorokból nem a győztes vagy éppen a vesztes, hanem a felül- vagy alulreprezentált párt eredménye tủnik ki, jelezve annak kimagasló támogatottságát, illetve szavazóbázisának hiányát. Ezzel az adat-transzformációval, végeredményben standardizálással, ki lehetett szürni az egyes pártok aktuális támogatottságából eredő eltéréseket. A választási adatokhoz dinamikus és statikus társadalomstatisztikai adatokat rendeltünk, ezek többsége a KSH 2001 -es népszámlálásából, továbbá a T-STAR, a TEIR nyilvános adatbázisából származik (1. táblázat). ${ }^{2}$

\section{A téma kutatásának nemzetközi elözményei}

A városközpontok és agglomerációk választásföldrajzi elkülönülése az USA-ban már a II. világháború után kutatott témává vált, s számos könyv és folyóiratcikk a szuburbiák jobbra, a központ balra tolódásáról számolt be, bár voltak tanulmányok, amelyek régi, belső agglomerációs települések esetében is a baloldali pártok térnyeréséről írtak. A tendenciák regisztrálásán túl egyik visszatérő kérdéssé vált, hogy mi okozza a politikai polarizációt. Van-e szerepe a városközpontitól eltérö szuburbán társadalmi összetételnek, a szuburbiák ,polgárosulásának”, a jobboldali szavazók szelektív kivándorlásának, vagy éppen a szomszédsági hatásnak köszönhetö mindez? Lehetséges-e, hogy az eltérö életforma, a fogyasztási szokásokban, közlekedésben és a lakáspiacon megfigyelhető individuális-kollektív törésvonal eltérő politikai-ideológiai fejlödéssel jár? A későbbi vizsgálatok, amelyek közül jó néhány egyén szintủ adatbázison tesztelte a szomszédsági hatásokat, megerősítették a korábbi feltevéseket, miszerint a választópolgárok szavazata sokkalta jobban fuigg a térbeli helyzetüktöl, mint a társadalmi tagozódásuktól. Söt, az USA-ban és Kanadában a szuburbanizáció úgy hozott hasonló politikai változásokat a városrégiókban, hogy utóbbi országban hiányzik a belsö városrészek gettósodásának, a városrégiók politikai szembenállásának problémája (Cox 1968; Johnston-Pattie et al. 2001; De Maesschalck-Loopmans 2003; Johnston-Jones et al. 2004; Walks 2004; 2005; 2006).

Az egyesült királysági viszonyok között elöször Cox (1968) végzett vizsgálatot és az amerikai folyamatok meglétét igazolta a londoni városrégióban is. Évtizedekkel 
később Walks (2005) árnyalta a szigetországi képet: a jobbra tolódást a külső szuburbiákban igazolta kétséget kizáróan, míg a régebbi, belső szuburbán zónában a baloldali pártok változó mértékủ sikerét mutatta ki, s így a belső gyürủ szerepét a mérleg nyelveként interpretálta. Ám a központ-periféria politikai polarizáció nem csak a választói magatartásban érhetö tetten, hanem a politikai pártok éles elkülönülésében is (Agnew et al. 2002; De Maesschalck-Loopmans 2003; De Maesschalck 2004).

\section{Politikai háttér}

Az elemzésbe bevont pártok szavazóbázisának részletes ismertetésére terjedelmi okok miatt nincs mód, azonban a pártpreferenciák és a választók lakóhelye (Budapest, városok, falvak) közötti általános összefüggések bemutatását szükségesnek tartjuk a tanulmány eredményeinek megfelelő értelmezéséhez.

Az MDF támogatottságának településtípusonkénti megoszlása a vizsgált időszak egészében kiegyenlítettnek mondható, azzal, hogy legtöbb támogatója a vidéki városok közül került ki. Amilyen nagy a MIÉP és az SZDSZ közötti távolság ideológiai értelemben, oly annyira hasonlóak abban, hogy szavazataik jelentős többségét városi térségekben, elsősorban a fövárosban gyüjtik össze. A szabaddemokraták fővárosi befolyása közismert, a liberális párt urbánus jellege 2002 és 2006 között is növekvö tendenciát mutatott (Karácsony 2006). Az SZDSZ-hez hasonlóan a MIÉP szavazóbázisa is föként Budapestre és Pest megyére koncentrálódik. A lakóhely szerinti megoszlás másik pólusát az FKGP képezi, melynek szavazóbázisa mind településtípus szerint, mind pedig regionálisan jól körülhatárolható. Választási eredményük országos átlagához viszonyítva meglehetôsen rossz eredményt értek el a fövárosban, illetve a nagyobb városokban, ellenben átlagon felül szerepeltek a falusias agrárterületeken, kiváltképp a Dél-Alföldön és a Dél-Dunántúlon (SzarvasTóth 2003). Az MSZP támogatottsága az 1990. évi választások esetében az átlagosnál nagyobb volt a fövárosban, ezt követöen azonban kiegyenlítődött, településtípusonként viszonylag azonos mértékủ támogatásban részesült. A Fidesz szavazatokat az 1990-es évek elején némileg magyarázta a városi lakóhely, a párt ideológiai váltásával párhuzamosan azonban egyre inkább jobb eredményeket ért el a községekben (Körösényi 1998; Kovács Z. 2000; 2001).

A szavazóbázisok jellemzése során mindenképpen figyelembe kell venni a pártok támogatottságának nagyarányú változását is, amely hatással van a szavazótáborok összetételére. A szavazatok jelentős mértékủ növekedése „néppártibb” szavazótáborhoz, a szavazóbázis karakterességének mérséklödéséhez vezethet (pl. MDF 1990, MSZP 1994). 
Jankó Ferenc - Komornoki Mihály : Szuburbanizáció és választási földrajz:

Átalakuló pártválasztás Budapest térségében.

Tér és Társadalom 22. évf. 2008/4. 115-134. p.

TÉT XXII. évf. 2008 - 4

\section{A pártok támogatottságának változása Budapesten és Pest megyében}

Az alapproblémát elöször aggregált területi szinten vizsgáljuk meg. A hivatalos választási eredményekből látszik már, hogy a FIDESZ az első választást kivéve mindig átlag alatt teljesített Budapesten, az agglomerációban már jobban, de leginkább a megye agglomeráció nélküli részében. Az MSZP az utóbbi néhány választáskor éppen ellenkezőleg, a fővárosban volt erősebb, a többi területi relációban már gyengébb. Az is közismert, hogy az MDF és az SZDSZ nagyrészt budapesti eredményének köszönhette a 2006-os parlamentbe jutást. Egymáshoz viszonyítva a pártokat megállapíthatjuk, hogy a fővárosban 1990-ben szoros eredménnyel, de az MDF végzett az SZDSZ előtt, 1994 óta pedig MSZP győzelem született. Az agglomerációban az első voksolás idején az MDF, s utána ugyancsak végig az MSZP végzett az első helyen, ám sokkal élesebb volt a küzdelem a FIDESZ-szel, különösen 1998-ban. Pest megyének az agglomeráción kívül eső részében jelentös MDF siker született az SZDSZ ellenében (bár az FKGP is erős volt), majd a kilencvenes évek másik két szavazásán a baloldal, a 2000-es évek választásain pedig újra a jobboldal győzedelmeskedett (2. táblázat).

\section{TÁBLÁZAT}

A pártok listás választási eredményei, 1990-2006 (\%)

(Election Results of Party Lists, 1990-2006)

\begin{tabular}{|c|c|c|c|c|c|c|c|c|c|c|c|c|}
\hline & 1990 & 1994 & 1998 & 2002 & 2006 & & 1990 & 1994 & 1998 & 2002 & 2006 & \\
\hline \multirow{5}{*}{ 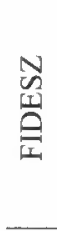 } & 11,5 & 6,2 & 26,5 & 31,6 & 35,1 & Budapest & 28,4 & 14,9 & 3,7 & & 5,3 & \\
\hline & 10,8 & 7,0 & 28,2 & 38,5 & 40,0 & Agglomeráció & 26,8 & 12,0 & 3,7 & & 5,4 & \\
\hline & 8,4 & 7,0 & 26,7 & 45,9 & 46,2 & Pest-Aggl. & 24,9 & 12,0 & 3,6 & & 4,8 & \\
\hline & 9,8 & 7,0 & 27,7 & 41,0 & 42,1 & Pest megye & 26,6 & 12,0 & 3,7 & & 5,2 & \\
\hline & 9,0 & 7,0 & 29,5 & 41,1 & 42,0 & Országos & 24,7 & 11,7 & 2,8 & & 5,0 & \\
\hline \multirow{5}{*}{$\underset{\Sigma}{N}$} & 12,9 & 35,2 & 33,1 & 44,1 & 43,8 & Budapest & 27,2 & 20,8 & 11,0 & 9,6 & 12,3 & \multirow{5}{*}{$\underset{N}{N}$} \\
\hline & 8,9 & 30,0 & 29,1 & 40,6 & 41,5 & Agglomeráció & 24,1 & 22,0 & 10,1 & 7,8 & 9,0 & \\
\hline & 9,2 & 29,6 & 29,2 & 39,6 & 41,1 & Pest-Aggl. & 19,9 & 18,5 & 6,6 & 4,4 & 4,3 & \\
\hline & 9,0 & 29,9 & 29,1 & 40,3 & 41,3 & Pest megye & 22,5 & 20,7 & 8,9 & 6,6 & 7,4 & \\
\hline & 10,9 & 33,0 & 32,9 & 42,1 & 43,2 & Országos & 21,4 & 19,7 & 7,6 & 5,6 & 6,5 & \\
\hline
\end{tabular}

Forrás: valasztas.hu, vokscentrum.hu alapján saját számítás.

Az egyes pártok területegységek közötti eróviszonyait, illetve mérlegét jól illusztrálja a Walks (2005) által központ-szuburbia egyensúlyi indexnek (city-suburban balance) nevezett mutató, amelyet a pártok adott területen kapott szavazatarányainak hányadosából kapunk meg (1-2. ábra). A két ábra összevetéséből látható, hogy a legkiegyenlítettebb párt az MSZP, amelynek korábbi Budapest-koncentráltsága sokat oldódott. Az SZDSZ viszont mindkét relációban éles koncetrálódáson ment keresztül. A FIDESZ esetében pedig mind a „Budapest-agglomeráció”, mind az ,agglomeráció-Pest megye” mérleg az utóbbiak javára billent át. 
Jankó Ferenc - Komornoki Mihály : Szuburbanizáció és választási földrajz:

Átalakuló pártválasztás Budapest térségében.

Tér és Társadalom 22. évf. 2008/4. 115-134. p.

TÉT XXII. évf. 2008 @ 4

Gyors ténykép

\section{1. ÁBRA}

A FIDESZ, az MSZP és az SZDSZ területi mérlege (Budapest-Agglomeráció) (Regional Balance of FIDESZ, MSZP and SZDSZ [Budapest-Agglomeration])

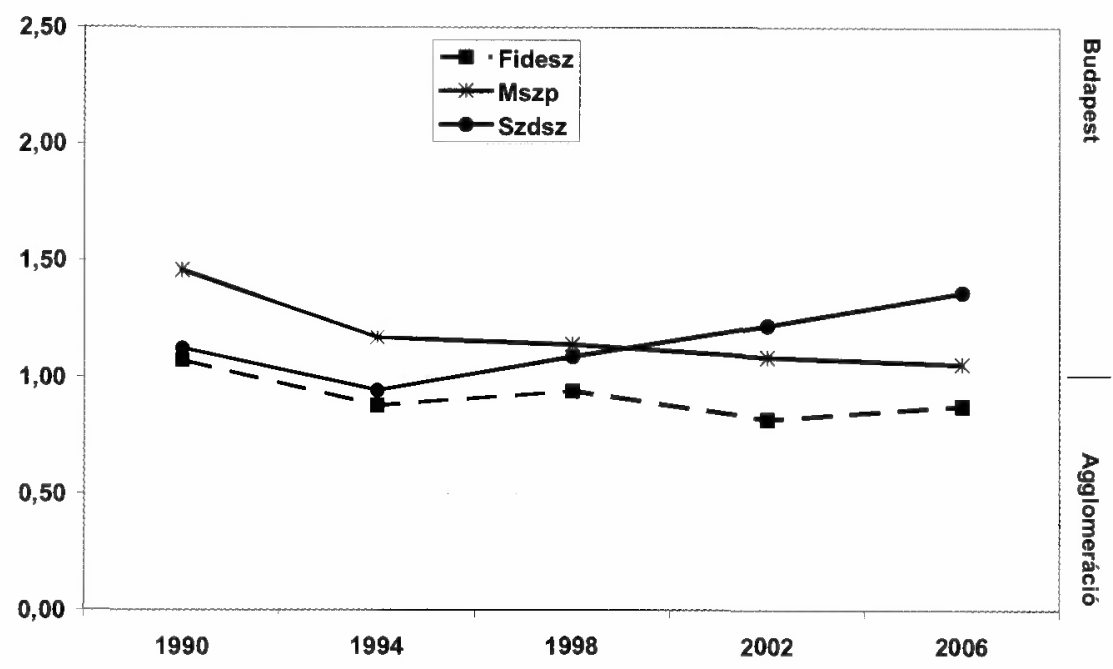

Forrás: Saját szerkesztés.

Az egyes pártok eredményét az országos átlaghoz viszonyítva a 3. táblázatot kapjuk, amely alapján a pártok relatív támogatottságának időbeli változását figyelhetjük meg. A FIDESZ ingadozó teljesítményt mutatott a vizsgált régiókban, egyértelmú tendencia nem rajzolódik ki. Az FKGP 1998-ig minden területen növelni tudta támogatottságát, arányaiban legkevésbé az agglomerációban, amellett, hogy mind a négy voksolás idején magasan átlag felett teljesített Pest megye agglomeráció nélküli felében, míg a budapesti városrégióban mélyen az országos eredményei alatt maradt. A MIÉP 1994-es indulásakor a leginkább föváros-központú pártnak bizonyult, majd szavazóbázisának folyamatos eróziója révén 2006-ra támogatottsága nivellálódott. Az MDF-et illetó tendenciák a 2002-es hiátus miatt nehezen láthatók. Annyi azonban bizonyos, hogy 1994-ig a fővárosban növelte támogatottságának arányát, s 1998-ra a jelentős növekedés mellett térségi kiegyenlítỏdés ment végbe. A legutóbbi választás idejére viszont amellett, hogy relatív támogatottsága az országos átlag köré esett, a fővárost övező szuburbán gyưrüben vált erösebbé. A FIDESZ-hez hasonlóan az MSZP esetében sem látható világos tendencia, ez úgy tủnik a nagy pártok sajátja. Ezzel szemben viszont az SZDSZ 2006-ra - az 1-2. ábráknak megfelelően - jelentősen növelte relatív támogatottságát a fövárosban, és némiképp kisebb mértékben az azt övező agglomerációban, mialatt a megye maradék részében fokozatosan vesztett erejéböl. 
Jankó Ferenc - Komornoki Mihály : Szuburbanizáció és választási földrajz:

Átalakuló pártválasztás Budapest térségében.

Tér és Társadalom 22. évf. 2008/4. 115-134. p.

\section{2. ÁBRA}

A FIDESZ, az MSZP és az SZDSZ területi mérlege

(Agglomeráció-Pest megye agglomeráció nélkül)

(Regional Balance of FIDESZ, MSZP and SZDSZ

[Agglomeration-County Pest without Agglomeration])

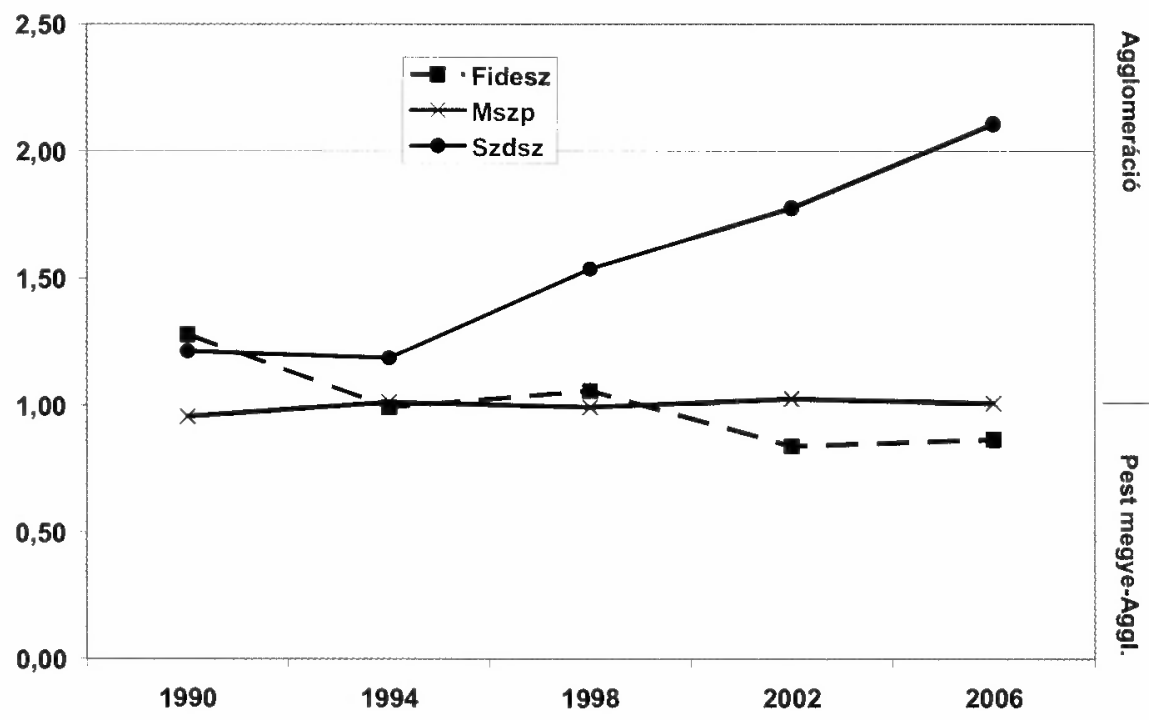

Forrás: Saját szerkesztés.

A pártok 3. táblázatban található értékeit egymással osztva a 3-4. ábrán látható diagrammokat kaptuk, amelyek az egymás közötti erőviszonyokat illusztrálják. ${ }^{3}$ A 3. ábrán látható, hogy a FIDESZ relatíve 1998-ig volt erősebb az agglomerációban, az utóbbi két választásra viszont átbillent a mérleg az MSZP javára. A FIDESZ támogatottságát a liberális párt eredményéhez mérve egy kinyíló ollót láthatunk. 1990-ben, amikor még a FIDESZ is liberálisnak számított, még „,budapestibb” pártnak lehetett mondani az SZDSZ-nél. 2002-re viszont a budapesti városrégió, azaz a főváros és agglomerációja egyre inkább a szabad demokratákat támogatta (2006-ra stagnálás figyelhető meg), míg vidéken, azaz a megye külső részében a FIDESZ oldalára billent át a mérleg (4. ábra).

Vagyis, bár a FIDESZ támogatottsága a központtól kifelé növekszik, az agglomerációban még átlag alatt marad, ahol sokkal jobban növelte pozícióját az MSZP és különösen a szabad demokraták pártja - viszont míg az SZDSZ a fövárosban méginkább erősödött, addig az MSZP eredményei nivellálódtak a területi szintek között. A FIDESZ egyre inkább rurális párt benyomását kelti, s ezzel a 2002-ig felszínen lévö FKGP-hez vált hasonlatossá. Az MDF is inkább urbánus pártnak mutatkozik, csakúgy, mint a radikális jobboldalt képviselő MIÉP, bár utóbbi párt „fóváros-centrikussága” a választási kudarcok révén 2006-ra elolvadt. 
Jankó Ferenc - Komornoki Mihály : Szuburbanizáció és választási földrajz: Átalakuló pártválasztás Budapest térségében.

Tér és Társadalom 22. évf. 2008/4. 115-134. p.

TÉT XXII. évf. 2008 - 4

Gyors ténykép

\section{TÁBLÁZAT}

A pártok listás választási eredményei az országos átlag százalékában, 1990-2006 (Election Results of Party Lists in Percentage of Country Average, 1990-2006)

\begin{tabular}{|c|c|c|c|c|c|c|c|c|c|c|c|c|}
\hline & 1990 & 1994 & 1998 & 2002 & 2006 & & 1990 & 1994 & 1998 & 2002 & 2006 & \\
\hline \multirow{4}{*}{$\begin{array}{l}N \\
N \\
\text { U్య } \\
\text { 总 }\end{array}$} & 8,8 & 87,6 & 0,0 & 6,9 & 5 & & 3 & 1 & 65,2 & 35,8 & & \multirow{4}{*}{$\stackrel{\pi}{\sigma}$} \\
\hline & 0,2 & 99,7 & 95,7 & 93,8 & 95,1 & ráció & 92,2 & 94,9 & 97,5 & 69,0 & & \\
\hline & 93,9 & 100,3 & 90,4 & 111,6 & 109,9 & Pest- & 135,1 & 131,9 & 150,4 & 135,0 & & \\
\hline & 0,0 & 99,9 & 93,9 & 9,9 & 100,1 & & 108,9 & 109,0 & 116,1 & 91,7 & & \\
\hline \multirow{4}{*}{ 诖 } & & 226,0 & 161,6 & 59,3 & 131,9 & Bud & 114,9 & 127,3 & 131 & & & \multirow{4}{*}{3} \\
\hline & & 5,7 & 6,9 & 2,7 & 5 & r & 108,4 & 102,2 & 132,8 & & 107 & \\
\hline & & 110,9 & 116,8 & 04,3 & 130,6 & 1 & 100,8 & 102,3 & 12 & & 95 & \\
\hline & & 157,3 & 8 & 9,5 & 1. & & 107,8 & 102,3 & 130,8 & & 103 & \\
\hline \multirow{4}{*}{$\frac{N}{N}$} & 118,5 & 106,5 & 100,6 & 104,9 & 101,3 & Bud & 126,9 & 105,2 & 145,7 & 171,4 & 188,9 & \multirow{4}{*}{$\underset{N}{N}$} \\
\hline & 81,2 & 1 & ,3 & 6 & 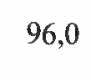 & $\begin{array}{r}\mathrm{Agg} \\
\text { rá }\end{array}$ & 112,9 & 111,5 & 133,9 & 140,4 & 138,6 & \\
\hline & 84,9 & 89,8 & 88,8 & 94,1 & 95,1 & Pest & 93,0 & 93,9 & 87,1 & 79,1 & 65,8 & \\
\hline & 82,7 & 90,6 & 8,5 & 5,8 & 95,7 & Pest megye & 105,1 & 104,8 & 117,5 & 119,3 & 114,2 & \\
\hline
\end{tabular}

Forrás: valasztas.hu, vokscentrum.hu alapján saját számítás.

\section{3. ÁBRA}

A FIDESZ és az MSZP országos átlaghoz viszonyitott eredményeinek hányadosa (Ratio of Election Results of FIDESZ and MSZP Compared to Country Average)

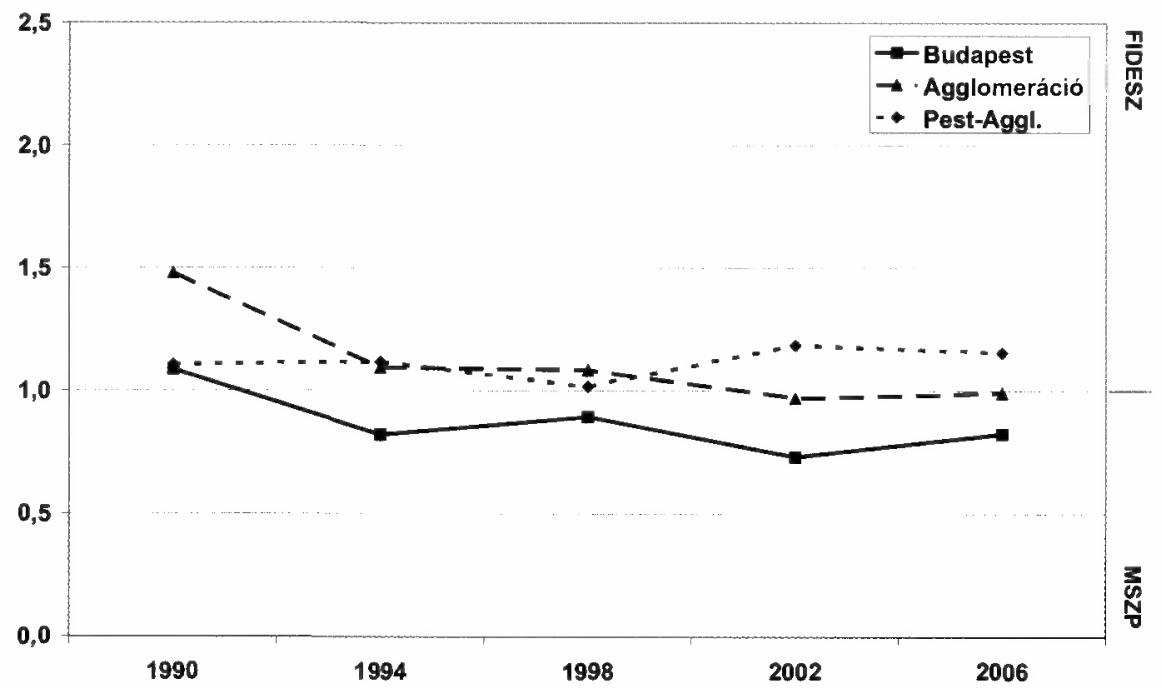

Forrás: Saját szerkesztés. 
Jankó Ferenc - Komornoki Mihály : Szuburbanizáció és választási földrajz:

Átalakuló pártválasztás Budapest térségében.

Tér és Társadalom 22. évf. 2008/4. 115-134. p.

\section{4. ÁBRA}

A FIDESZ és az SZDSZ országos átlaghoz viszonyitott eredményeinek hányadosa (Ratio of Election Results of FIDESZ and SZDSZ Compared to Country Average)

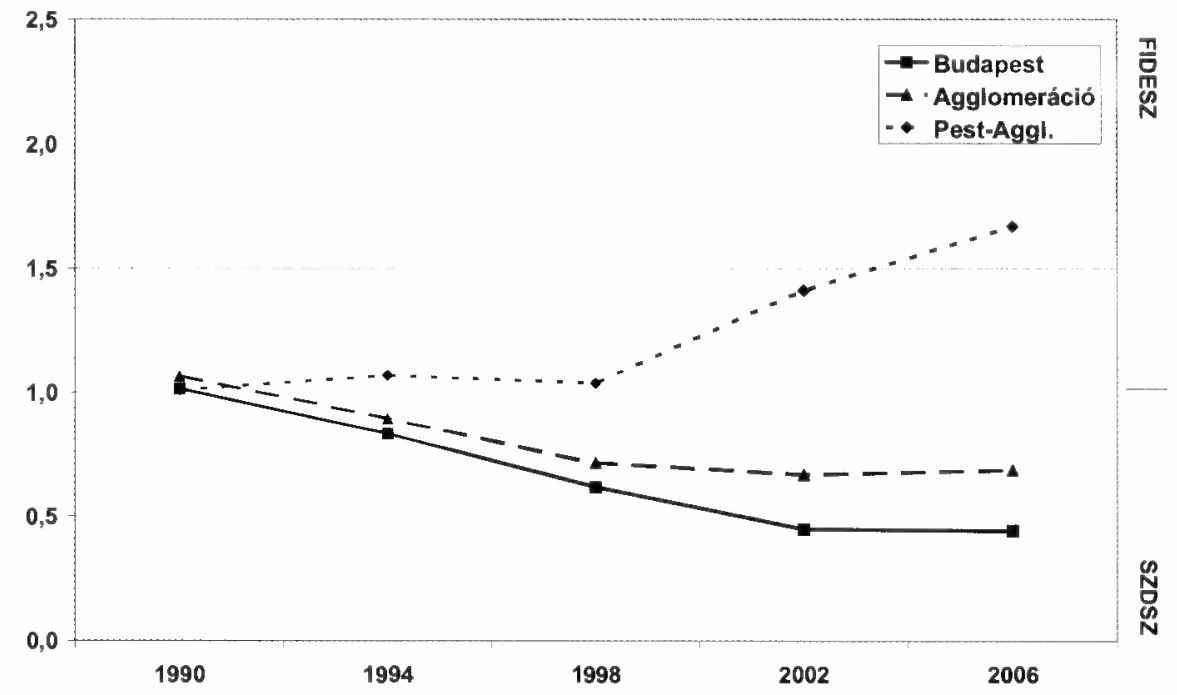

Forrás: Saját szerkesztés.

\section{Eltérō települési pályák a politikai térben}

A választói magatartás területi szerkezetének stabilitását korrelációszámítással vizsgáltuk meg, azaz a pártok egyes években elért eredményeinek együttmozgását tanulmányoztuk (4. táblázat). Az adatok a FIDESZ esetében jól jelzik a párt arculatváltozását, ugyanis az 1990-es eredmények mindegyik másik év adatával nagyon alacsony összefüggést mutatnak. A legutóbbi választás is csak a 2002-es struktúrával azonos, az 1998-as választások adatsorával már csak közepes erösségủ az összefuiggés. De a többi jobboldali párt korrelációs adatai is arra mutatnak rá, hogy a mai struktúrák csak részben fedik le a korábbiakat. További érdekesség, hogy az MDF 1990-es adatsora a FIDESZ egyetlen eredménysorával sem mutatott összefüggést, a korrelációs együttható minden év esetében 0,1 alatt maradt, sőt többnyire negatív volt. Az SZDSZ és az MSZP esetében viszont számottevően nagyobb fokú stabilitásról beszélhetünk, a baloldali párt 2006-os adatsora még az 1994-essel is 0,6 feletti korrelációt produkált. Ám összességében az adatok a pártok területi beágyazódásának viszonylagos instabilitását jelzik; a legutóbbi két választás idôpontja között viszont már egy potenciális stabilizálódási folyamatnak lehetünk szemtanúi (Karácsony 2006). ${ }^{4}$ 
Jankó Ferenc - Komornoki Mihály : Szuburbanizáció és választási földrajz:

Átalakuló pártválasztás Budapest térségében.

Tér és Társadalom 22. évf. 2008/4. 115-134. p.

TÉT XXII. évf. 2008 घ 4

Gyors ténykép

125

4. TÁBLÁZAT

A pártok országos átlaghoz viszonyitott eredményeinek idöbeli korrelációi

(Correlations in Time between Polls Compared to Country Average)

\begin{tabular}{lccccc}
\hline & 1990 & 1994 & 1998 & 2002 & 2006 \\
\hline FIDESZ 1990 & 1,000 & $-0,075$ & $0,146^{*}$ & $-0,186^{*}$ & $-0,175^{*}$ \\
FIDESZ 2006 & $-0,175^{*}$ & $0,415^{* *}$ & $0,470^{* *}$ & $0,918^{* *}$ & 1,000 \\
\hline FKGP 1990 & 1,000 & $0,673^{* *}$ & $0,604^{* *}-$ & $0,307^{* *}$ & - \\
FKGP 2002 & $0,307^{* *}$ & $0,383^{* *}$ & $0,520^{* *}$ & 1,000 & - \\
\hline MDF 1990 & 1,000 & $0,442^{* *}$ & $0,558^{* *}$ & - & $0,147^{*}$ \\
MDF 2006 & $0,147^{*}$ & $0,163^{*}$ & $0,251^{* *}$ & - & 1,000 \\
\hline MIÉP 1994 & - & 1,000 & $0,422^{* *}$ & $0,369^{* * *}$ & $0,226^{* *}$ \\
MIÉP 2006 & - & $0,226^{* *}$ & $0,516^{* *}$ & $0,596^{* *}$ & 1,000 \\
\hline MSZP 1990 & 1,000 & $0,556^{* *}$ & $0,556^{* *}$ & $0,291^{* *}$ & $0,230^{* *}$ \\
MSZP 2006 & $0,230^{* *}$ & $0,658^{* *}$ & $0,605^{* *}$ & $0,905^{* *}$ & 1,000 \\
\hline SZDSZ 1990 & 1,000 & $0,495^{* *}$ & $0,406^{* *}$ & $0,346^{* *}$ & $0,290^{* *}$ \\
SZDSZ 2006 & $0,290^{* *}$ & $0,438^{* *}$ & $0,608^{* *}$ & $0,856^{* *}$ & 1,000 \\
\hline
\end{tabular}

Megjegyzés: * $\mathrm{p}<0,05 * * \mathrm{p}<0,01$

Forrás: Saját számítás.

De vajon az egyes települések milyen politikai arculattal rendelkeznek, illetve milyen pályát futottak be a politikai térben? Erre a kérdésre klaszteranalízis segítségével kerestük a választ. Számtalan vizsgálatot lefuttattunk, hiszen az adatok kombinálási lehetőségei gyakorlatilag kimeríthetetlenek voltak. A települések tipizálása során eldöntendő volt, hogy valamennyi jelentősebb párt figyelembe vétele esetén mely évek adatát szerepeltessük. A FIDESZ, MDF, SZDSZ és MSZP esetén természetesen a 2006-os eredményekkel számoltunk, azonban az FKGP és a MIÉP 1998-as adatait tettük az alábbi modellbe, mivel a 2002-es, illetve a MIÉP esetében a 2006-os választási eredmények oly mértékig eluralkodtak a klaszteranalízisen, hogy egy-egy önálló klaszter jött létre néhány szélsőséges adattal bíró település miatt. A hat párt választási eredményét és a 2006-os részvételi arányt is figyelembe véve az alább közölt modellben hat típus alkotását kértük az SPSS programtól, amely a K-Means klaszterezési eljárással az 5. táblázatban közölt és az 5. ábrára felrajzolt csoportokat állította elö.

Az elnevezésekkel is érzékeltetni próbáljuk, hogy az első és az ötödik klaszter az, amelyben az SZDSZ támogatottsága magasan országos átlag feletti arányú. Az első klaszterben ehhez erős MIÉP-es szavazóbázis társul, azaz karakteresen urbánus szavazóbázisú települések kaptak ebben helyet. Ám még a négyes klaszter is inkább városiasnak mondható, hiszen az erős MIÉP mellett a liberálisok eredménye országos átlag körül mozog. Az 5. ábrán jól látható, hogy az urbánus politikai arculatú települések javarészt az agglomerációban találhatók, különösen annak északi és nyugati felén. 
Jankó Ferenc - Komornoki Mihály : Szuburbanizáció és választási földrajz: Átalakuló pártválasztás Budapest térségében.

Tér és Társadalom 22. évf. 2008/4. 115-134. p.

\section{TÁBLÁZAT}

A települések pártpreferencia-típusai, a klaszterközpontok értékei és a típusba tartozó települések száma

(Party-preference Clusters, Values of Cluster Centres and Number of Settlements)

\begin{tabular}{|c|c|c|c|c|c|c|}
\hline & 1. & 2. & 3. & 4. & 5. & 6. \\
\hline Mutatók: & $\begin{array}{l}\text { Urbánus } \\
\text { (21) }\end{array}$ & $\begin{array}{l}\text { Konzervativ- } \\
\text { rurális } \\
\text { (48) }\end{array}$ & $\begin{array}{c}\text { Mérsékelten } \\
\text { jobboldali } \\
\text { (44) }\end{array}$ & $\begin{array}{c}\text { Szélsőjobb } \\
\text { és konzerva- } \\
\text { tív (37) }\end{array}$ & $\begin{array}{c}\text { Mérsékelten } \\
\text { urbánus } \\
\text { (28) }\end{array}$ & $\begin{array}{c}\text { Radikális } \\
\text { (4) }\end{array}$ \\
\hline FKGP 1998 & 80,47 & 194,53 & 114,22 & 110,15 & 110,36 & 139,02 \\
\hline MIÉP 1998 & 179,25 & 99,08 & 91,29 & 179,96 & 111,56 & 364,37 \\
\hline $\begin{array}{l}\text { Részvétel } \\
2006\end{array}$ & 75,78 & 60,95 & 66,29 & 69,98 & 69,60 & 65,63 \\
\hline $\begin{array}{l}\text { FIDESZ } \\
2006\end{array}$ & 99,16 & 112,49 & 109,69 & 109,49 & 92,26 & 119,88 \\
\hline MDF 2006 & 107,73 & 86,44 & 96,77 & 110,60 & 102,20 & 90,32 \\
\hline MSZP 2006 & 85,03 & 95,69 & 95,45 & 87,47 & 100,20 & 79,36 \\
\hline SZDSZ 2006 & 185,09 & 60,55 & 63,44 & 93,90 & 137,67 & 63,72 \\
\hline
\end{tabular}

Forrás: Saját számítás.

\section{5. ÁBRA}

A Pest megyei települések pártpreferencia-típusai (Party-preference Clusters of Settlements in County Pest)

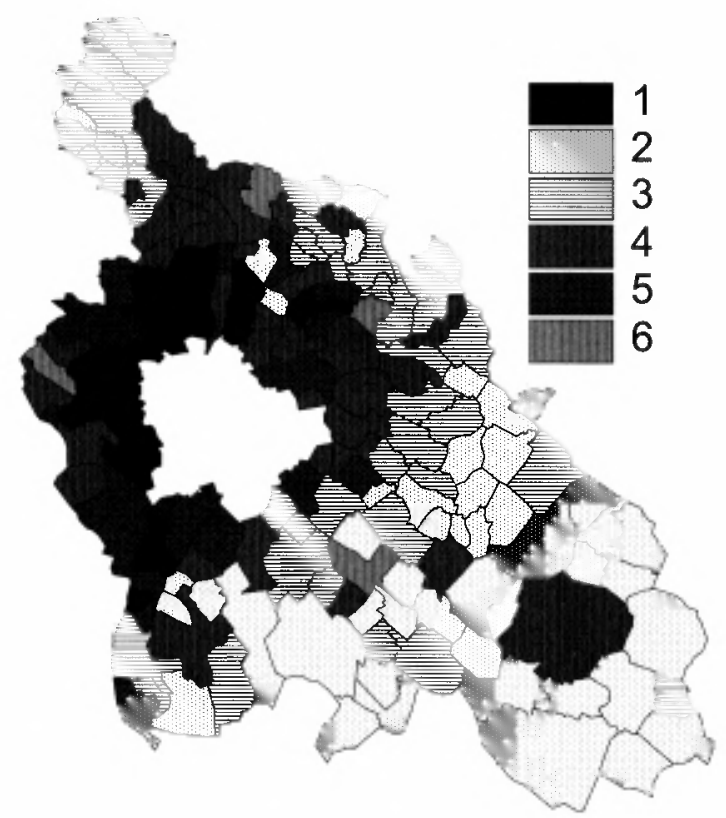

Jelmagyarázat: 1. Urbánus klaszter (21) 2. Konzervatív-rurális (48) 3. Mérsékelten jobboldali (44) 4. Szélsőjobb és konzervativ (37) 5. Mérsékelten urbánus (28) 6. Radikális (4)

Forrás: Saját szerkesztés. 
Jankó Ferenc - Komornoki Mihály : Szuburbanizáció és választási földrajz: Átalakuló pártválasztás Budapest térségében.

Tér és Társadalom 22. évf. 2008/4. 115-134. p.

A pártok támogatottságának dinamikája tekintetében egy olyan klaszteranalízis eredményét mutatjuk be, ahol csak három párt (FIDESZ, MSZP, SZDSZ) adatát vettük figyelembe, mégpedig a 2006 és 1994, a FIDESZ esetében 2006 és 1998 közötti tendencia mutatóját, mivel az 1990-es, illetve 1994-es eredmények még egy lényegesen más struktúrában születtek. A 6. táblázat a négy eredmény-klaszter középpontjának az adatait mutatja be, amelyek közül kettőben - az elsőben és a negyedikben - az SZDSZ relatív térnyerése a döntö, míg egyben inkább az MSZP-é, egyben pedig a FIDESZ-é.

\title{
6. TÁBLÁZAT
}

A települések dinamikus pártpreferencia-típusai, a klaszterközpontok értékei és a típusba tartozó települések száma

(Dynamic Party-preference Clusters, Values of Cluster Centres and Number of Settlements)

\begin{tabular}{lcccc}
\hline \multirow{2}{*}{ Mutató } & 1. & 2. & 3. & 4. \\
\cline { 2 - 5 } & $\begin{array}{c}\text { Urbánus } \\
(44)\end{array}$ & $\begin{array}{c}\text { Baloldali- } \\
\text { rurális (91) }\end{array}$ & $\begin{array}{c}\text { Konzervatív- } \\
\text { rurális (35) }\end{array}$ & $\begin{array}{c}\text { Erösen } \\
\text { urbánus (12) }\end{array}$ \\
\hline FIDESZ 2006/1998 & 1,04 & 1,11 & 1,59 & 1,13 \\
MSZP 2006/1994 & 1,04 & 1,21 & 1,00 & 0,95 \\
SZDSZ 2006/1994 & 1,44 & 0,78 & 0,75 & 2,44 \\
\hline
\end{tabular}

Forrás: Saját számítás.

\author{
6. ÁBRA
}

A Pest megyei települések dinamikus pártpreferencia-tipusai (Dynamic Party-preference Clusters of Settlements in County Pest)

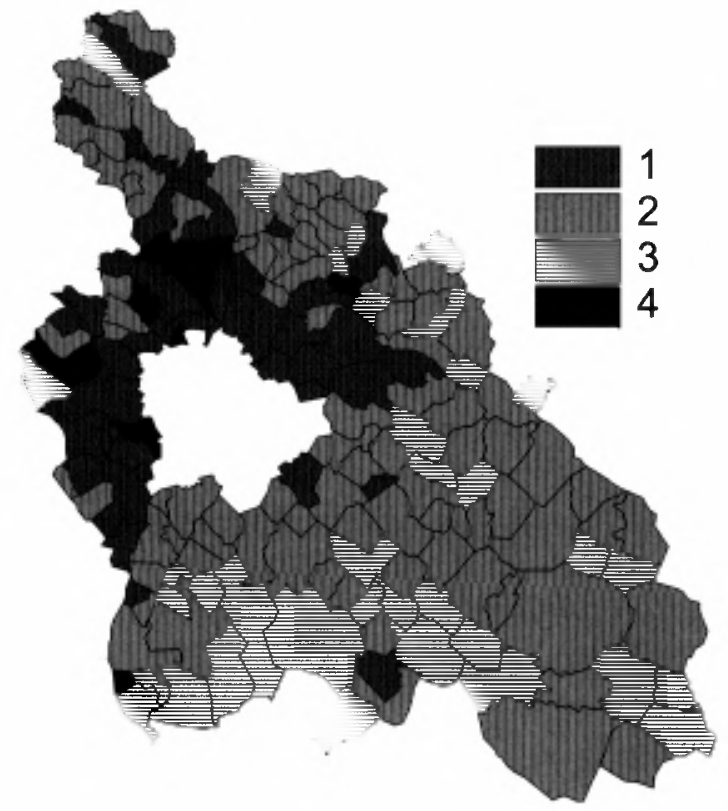

Jelmagyarázat: 1. Urbánus dinamika (44) 2. Baloldali-rurális dinamika (91)

3. Konzervatív-rurális dinamika (35) 4. Erösen urbánus dinamika (12)

Forrás: Saját szerkesztés. 
Jankó Ferenc - Komornoki Mihály : Szuburbanizáció és választási földrajz:

Átalakuló pártválasztás Budapest térségében.

Tér és Társadalom 22. évf. 2008/4. 115-134. p.

A vonatkozó 6. ábrán az elözỏhöz hasonló térszerkezetet figyelhetünk meg, talán csak a déli agglomerációs szektor az, amelynek települései a délkeletiekhez csatlakozva ehelyütt a baloldali-rurális klaszterba nyertek besorolást. Mindemellett azonban könnyen belátható, hogy az agglomerációban, annak is északi és nyugati felében az urbánus szavazóbázisú pártok, azaz mindenekelött az SZDSZ relatív támogatottsága növekedett.

\section{A választói magatartás és a szuburbanizáció összefüggése}

Az előző eredménnyel azonban még nem kerültünk a legközelebb az előzetesen feltett fö kérdésünk megválaszolásához. Természetesen, hogy az ökológiai tévkövetkeztetés hibáját teljes mértékben kivédjük, választópolgár szintủ adatbázis felépitésével és felhasználásával kellene a kérdést megválaszolnunk. Ennek hiányában település szintü adatokkal operálva próbáltuk a lehetséges válaszokat megfogalmazni, amelyre több vizsgálati út kínálkozott. Elöször a többváltozós regresszió módszerét alkalmazva azt kutattuk, hogy az egyes pártok választási eredményeinek, mint függô változóknak mely mutatók magyarázzák a szóródását, és milyen erősségú modellben teszik mindezt.

A 7. táblázatban azon regressziós modellek eredményét foglaljuk össze, ahol 0,3 feletti együttható adódott. Látható, hogy a legjobban illeszkedő függvények az SZDSZ mutatói kapcsán születtek, érdekes módon a többségében 2001-es adatokkal a 2006-os eredmény produkált már igencsak erős összefuiggést. Érdemes elidőzni a „Backward” módszerrel dolgozó többváltozós regresszió mutatószelektálásának eredményeinél, ahol a bent maradt változókat erősségük sorrendjében tüntettük fel. Eredményeink az egész magyar választói társadalomra is kivetíthetö megállapításokat sugallnak, összefüggésben a politikatudomány törésvonal elméletével és a választási magatartás szociológiai modelljével. ${ }^{5}$ Úgy tünik, hogy a foglalkozás, a végzettség, a családnagyság, a vallásosság továbbra is éles választóvonalat képez a magyar társadalomban, e mutatók rendre a modellek részét képezik. $S$ jól látható az is, hogy a FIDESZ korántsem csak a gyermekes családok pártja (vö. az MSZP eredményeivel), hanem sokkal inkább a rurális térségeké, hiszen az egyszemélyes háztartások változóját rendre ott találjuk a modellekben. Az SZDSZ pedig egyértelmúen az értelmiségiek, a városias életformát viselök pártjának mutatkozik, bár sokhelyüitt lelhetünk a közéletből ismert sztereotípiákkal ellentétes értelmú mutatókra is. 
Jankó Ferenc - Komornoki Mihály : Szuburbanizáció és választási földrajz: Átalakuló pártválasztás Budapest térségében.

Tér és Társadalom 22. évf. 2008/4. 115-134. p.

TÉT XXII. évf. 2008 - 4

Gyors ténykép

7. TÁBLÁZAT

A többváltozós regresszió-modellek eredményének összegzése

(Summary of Multivariate Regression Models)

\begin{tabular}{|c|c|c|}
\hline $\begin{array}{l}\text { Függö válto- } \\
\text { zó }\end{array}$ & $R^{2}$ & Független változók a magyarázó erö sorrendjében \\
\hline FIDESZ02 & 0,432 & $\begin{array}{l}\text { IPARI, FELNELK, GYERMEK014, EGYSZHÁZT, ÉLETTCSAL, } \\
\text { SZEKUND, ESZELL, PRIMER, ELERES, MÜKVÁLL, ELJFOGL, } \\
\text { FIATAL2024 }\end{array}$ \\
\hline FIDESZ06 & 0,441 & $\begin{array}{l}\text { IPARI, GYERMEK014, FELNELK, SZEKUND, GYERMHÁZ, } \\
\text { MÚKVÁLL, ESZELL, PRIMER, FIATAL2024, ELERES, EP4589, } \\
\text { ÉLETTCSAL, SZOLG, FELNOTT4059, ELJFOGL }\end{array}$ \\
\hline FKGP02 & 0,331 & $\begin{array}{l}\text { MEZOGAZD, ELERES, IPARI, SZEKUND, ÁLTISKSEM10, } \\
\text { ÉLTGYER }\end{array}$ \\
\hline MIÉP02 & 0,387 & $\begin{array}{l}\text { FFOK25, POP0190, MEZOGAZD, VANDKUL100, ESZELL, SZE- } \\
\text { KUND, SZOLG, EGYEB, FURDO100, HELYDOLG, EP4589 }\end{array}$ \\
\hline MSZP02 & 0,363 & $\begin{array}{l}\text { IPARI, GYERMEK014, FELNELK, MÜKVÁLL, ESZELL, } \\
\text { EGYSZHÁZT, SZEKUND, ELERES, 4SZOB, ELJFOGL, } \\
\text { SZGKPOP, GYERMHÁZ, ELETTCSAL, FIATAL2024, EP4589 }\end{array}$ \\
\hline MSZP06 & 0,445 & $\begin{array}{l}\text { PRIMER, IDOS60X, FFOK25, FELNELK, IPARI, SZEKUND, } \\
\text { GYERMHÁZ, MÚKVÁLL }, \text { EGYSZHÁZT, GYERMEK014, } \\
\text { ELJFOGL, ELERES, SZOLG, EP4589, ÉLETTCSAL, EGYSZOB }\end{array}$ \\
\hline SZDSZ02 & 0,444 & $\begin{array}{l}\text { FURDO100, FFOK25, ÉLETTCSAL, ÁLTISKSEM10, SZGKPOP, } \\
\text { FIATAL2024 }\end{array}$ \\
\hline SZDSZ06 & 0,706 & $\begin{array}{l}\text { FFOK25, ELERES, EP9001, FURDO100, FIATAL2024, 4SZOB, } \\
\text { ÉLETTCSAL, ÁLTISKSEM10, GYERMEK014, FELNOTT4059 }\end{array}$ \\
\hline SZDSZ0694 & 0,634 & $\begin{array}{l}\text { FFOK25, FIATAL2024, FELNOTT4059, POP0190, ELERES, } \text { SZE- } \\
\text { KUND, } \text { HELYDOLG, MÜKVÁLL, MUNKRAT, EGYSZOB, } \\
\text { ÁLTISKSEM10, } \underline{\text { SZOB }} \text {, } \underline{\text { SZOLG }}\end{array}$ \\
\hline FIDESZ0698 & 0,444 & $\begin{array}{l}\text { MEZOGAZD, FURDO100, GYERMEK014, GYERMHÁZ, } \\
\text { FFOK25, EP9001, SZOLG, ÉLTGYER, EGYYSZHÁZ, FELNELK, } \\
\text { SZEKUND, 4SZOB, EGYEB, SZGKPOP, ÁLTISKSEM10 }\end{array}$ \\
\hline
\end{tabular}

Megjegyzés: Az aláhúzott változók kapcsolata fordított arányú.

Forrás: Saját számítás.

Ahhoz, hogy a többváltozós regresszió interpretálásának nehézségén átlépjünk, a szakirodalmi áttekintésben tárgyalt Cox (1968) eljárásához hasonlóan a mutatók sủrítése mellett döntöttünk. A komplex mutatókat nem a magyar szakirodalomban elterjedtté vált „szuburbanizációs index” módszerével, hanem fókomponensanalízissel (PCA) állítottuk elő; azaz a hipotetikusan kiválasztott mutatók információtartalmát az SPSS programmal egy változóba sủrítettük össze. Ez többnyire néhány iteráció, egy-egy mutató kiszelektálása után sikerrel járt (8. táblázat). 
Jankó Ferenc - Komornoki Mihály : Szuburbanizáció és választási földrajz:

Átalakuló pártválasztás Budapest térségében.

Tér és Társadalom 22. évf. 2008/4. 115-134. p.

\section{TÁBLÁZAT}

A fókomponensek komponens mátrixai (1)

(Matrixes of Principal Components [1])

\begin{tabular}{|c|c|c|c|c|c|}
\hline$P C A 1$ & $P C A 2$ & $P C A 3$ & $P C A 4$ & PCAS & \\
\hline Variancia $\%$ & 58,84 Variancia $\%$ & 70,11 Variancia $\%$ & 65,92 Variancia $\%$ & 73,41 Variancia $\%$ & 69,68 \\
\hline FELNOTT4059 & 0,568 VANDKUL100 & 0,835 FIATAL2024 & $-0,604$ EGYSZOB & 0,669 ELJDOLG & $-0,835$ \\
\hline FFOK25 & 0,848 POP0190 & 0,899 IDOS60X & 0,925 ÉLETTCSAL & 0,966 PRIMER & 0,835 \\
\hline 4SZOB & 0,788 FFOK25 & 0,797 ELERES & 0,751 ÉLTGYER & 0,907 & \\
\hline FURDO100 & 0,853 4SZOB & 0,706 GYERMHÁZ & $-0,903$ & & \\
\hline PRIMER & -0,622 ЕР9001 & 0,931 EGYSZHÁZT & 0,834 & & \\
\hline VEZERT & 0,857 & & & & \\
\hline ELERES & $-0,812$ & & & & \\
\hline SZGKPOP & 0,583 & & & & \\
\hline MUNKRAT & $-0,740$ & & & & \\
\hline JÖVPOP & 0,827 & & & & \\
\hline MÜKVÁLL & 0,855 & & & & \\
\hline
\end{tabular}

Forrás: Saját számítás.

\section{TÁBLÁZAT}

A főkomponensek komponens mátrixai (1) és a faktoranalizis rotált faktormátrixa (Matrixes of Principal Components [1] and Rotated Factor Matrix of Factoranalyses)

\begin{tabular}{lllcc}
\hline \multicolumn{1}{c}{ PCA12 } & \multicolumn{1}{c}{ PCA345 } & FAKTORI & FAKTOR2 \\
\hline Variancia \% & 53,07 Variancia \% & 53,16 Variancia \% & 33,90 & 19,86 \\
FELNOTT4059 & 0,510 PRIMER & 0,606 FELNELK & 0,613 & 0,310 \\
FFOK25 & 0,874 FELNELK & $-0,578$ EGYSZOB & & 0,905 \\
4SZOB & 0,795 MUNKRAT & 0,687 4SZOB & 0,580 & $-0,558$ \\
FURDO100 & 0,817 JÖVPOP & $-0,690$ FURDO100 & 0,712 & $-0,525$ \\
PRIMER & $-0,607$ IDOS60X & 0,782 ELERES & $-0,857$ & \\
VEZERT & 0,868 ELERES & 0,863 SZGKPOP & 0,509 & \\
ELERES & $-0,815$ GYERMHÁZ & $-0,818$ MUNKRAT & $-0,678$ & 0,347 \\
SZGKPOP & 0,559 EGYSZHÁZT & 0,760 JÖVPOP & 0,695 & \\
MUNKRAT & $-0,720$ & ÉLETTCSAL & & 0,569 \\
JÖVPOP & 0,795 & GYEMRHAZ & 0,600 & \\
MÜKVÁLL & 0,792 & FELNOTT4059 & 0,433 & $-0,323$ \\
EP9001 & 0,772 & & & \\
VANDKUL100 & 0,543 & & & \\
POP0190 & 0,582 & & & \\
\hline
\end{tabular}

Megjegyzés: A faktormátrixban az abszolút értékben 0,25-nél kisebb súlyokat nem szerepeltettük.

Forrás: Saját számítás. 
Jankó Ferenc - Komornoki Mihály : Szuburbanizáció és választási földrajz:

Átalakuló pártválasztás Budapest térségében.

Tér és Társadalom 22. évf. 2008/4. 115-134. p.

A PCA1 és 2 komponens egyaránt a szuburbanizáció és egyúttal a társadalmi fejlettség mutatóit sủríti. A PCA3 a demográfiai erózió, a PCA4 a tradíció hiánya és a rossz lakáskörülmények (a vallás mutatóit nem sikerült a modellben tartani), a PCA5 pedig a ruralitás fökomponense. Kézenfekvőnek adódott, hogy egy következô vizsgálati körben az első kettő és a másik három fókomponens információtartalmát egy-egy fökomponensben foglaljuk össze (PCA12 és PCA345, urbánusrurális). Ezután a közismerten szigorúbb matematikai követelményrendszerủ és eltérỏ célú faktoranalízissel is sikerrel jártunk, két, együttesen az eredeti változószett 53\%-át magyarázó faktor jött ekkor létre, az utóbbi két fökomponenshez hasonló jelentéssel, bár összességében kisebb magyarázott hányaddal. Az eredmény elfogadása azonban a több, bár ellenkező előjellel mindkét faktoron rajta levő változó miatt megkérdőjeleződik (9. táblázat).

\section{TÁBLÁZAT}

A választási eredmények és a többdimenziós mutatók korrelációs táblája (Correlation Matrix of Election Results and Multi-dimensional Variables)

\begin{tabular}{|c|c|c|c|c|c|c|c|c|c|}
\hline & $P C A 1$ & $P C A 2$ & $P C A 3$ & $P C A 4$ & $P C A 5$ & $P C A 12$ & PCA345 & Faktorl & Faktor2 \\
\hline $\begin{array}{l}\text { Részvételi arány } \\
2002\end{array}$ & $0,690^{\circ *}$ & $0,512^{* *}$ & $-0,081$ & $-0,125$ & $-0,351^{* *}$ & $0,673^{* *}$ & $-0,329^{* * *}$ & $0,446^{* *}$ & $-0,310^{* *}$ \\
\hline FIDESZ 2002 & $-0,348^{* *}$ & $-0,265^{* *}$ & $0,382^{* * *}$ & $-0,058$ & $0,244^{* *}$ & $-0,356^{* *}$ & $0,480^{* * *}$ & $-0,510^{* *}$ & $-0,117$ \\
\hline FKGP 2002 & $-0,445^{* *}$ & $-0,256^{* *}$ & $0,221^{* *}$ & 0,089 & $0,459^{* * *}$ & $-0,423^{* *}$ & $0,365^{* *}$ & $-0,389^{* * *}$ & $0,210^{* *}$ \\
\hline MIÉP 2002 & $0,532^{* *}$ & $0,452^{* *}$ & $-0,251^{* *}$ & $-0,190^{*}$ & $-0,254^{m *}$ & $0,539^{* *}$ & $-0,386^{* *}$ & $0,476^{* *}$ & $-0,206^{* *}$ \\
\hline MSZP 2002 & $-0,037$ & $-0,085$ & $-0,205^{* *}$ & 0,135 & $-0,088$ & $-0,042$ & $-0,195^{* *}$ & $0,164^{*}$ & $0,217^{* *}$ \\
\hline SZDSZ 2002 & $0,583^{* *}$ & $0,543^{* *}$ & $-0,331^{* *}$ & $-0,008$ & $-0,273^{* *}$ & $0,610^{* * *}$ & $-0,503^{* *}$ & $0,593^{* *}$ & $-0,052$ \\
\hline $\begin{array}{l}\text { Részvételi arány } \\
2006\end{array}$ & $0,714^{* *}$ & $0,521^{* *}$ & $-0,163^{*}$ & $-0,192^{* *}$ & $-0,286^{* *}$ & $0,693^{* *}$ & $-0,391^{* *}$ & $0,511^{* *}$ & $-0,303^{* * *}$ \\
\hline FIDESZ 2006 & $-0,277^{* n}$ & $-0,194^{*+}$ & $0,332^{* *}$ & $-0,089$ & $0,286^{* *}$ & $-0,282^{* *}$ & $0,419^{* *}$ & $-0,436^{* *}$ & $-0,129$ \\
\hline MDF 2006 & $0,314^{* *}$ & $0,240^{* *}$ & $-0,233^{* *}$ & $-0,158^{*}$ & $-0,055$ & $0,307^{* *}$ & $-0,265^{* *}$ & $0,269^{* *}$ & $-0,148^{*}$ \\
\hline MIÉP 2006 & $0,157^{\circ}$ & 0,078 & $-0,072$ & $-0,217^{* *}$ & $-0,204^{* *}$ & 0,140 & $-0,111$ & 0,090 & $-0,176^{*}$ \\
\hline MSZP 2006 & $-0,126$ & $-0,177^{\circ}$ & $-0,112$ & $0,186^{*}$ & $-0,111$ & $-0,135$ & $-0,098$ & 0,075 & $0,248^{* *}$ \\
\hline SZDSZ 2006 & $0,749^{* *}$ & $0,729^{* *}$ & $-0,428^{* * n}$ & $-0,079$ & $-0,312^{* *}$ & $0,791^{* *}$ & $-0,629^{* *}$ & $0,722^{* *}$ & $-0,132$ \\
\hline FIDESZ 2006/1994 & $-0,125$ & $-0,086$ & 0,038 & 0,035 & $0,180^{*}$ & $-0,123$ & 0,090 & $-0,068$ & 0,068 \\
\hline FKGP 1998/1990 & $-0,240^{* *}$ & $-0,219^{* *}$ & $0,243^{* *}$ & $0,280^{\circ \circ}$ & 0,055 & $-0,253^{* *}$ & $0,305^{* *}$ & $-0,330^{* * *}$ & 0,082 \\
\hline MIEP 2002/1994 & $-0,182^{*}$ & $-0,110$ & 0,114 & 0,077 & 0,017 & $-0,169^{*}$ & 0,118 & $-0,120$ & 0,106 \\
\hline MDF 2006/1994 & 0,000 & 0,027 & $-0,222^{* *}$ & $-0,007$ & 0,030 & 0,012 & $-0,135$ & 0,075 & 0,000 \\
\hline MSZP 2006/1994 & $-0,207^{* *}$ & $-0,194^{* *}$ & $0,166^{\circ}$ & $0,191^{* *}$ & $-0,064$ & $-0,206^{* *}$ & $0,180^{*}$ & $-0,168^{*}$ & 0,114 \\
\hline SZDSZ 2006/1994 & $0,528^{* *}$ & $0,667^{* *}$ & $-0,246^{* *}$ & $-0,121$ & $-0,230^{* m}$ & $0,595^{* *}$ & $-0,379^{* *}$ & $0,436^{* *}$ & $-0,175^{*}$ \\
\hline FIDESZ 2006/1998 & $-0,509$ & $-0,376^{* *}$ & 0,273 & 0,126 & 0,360 & $-0,508$ & 0,433 & $-0,450$ & 0,159 \\
\hline MIEP 2006/1998 & $-0,167^{*}$ & $-0,144$ & 0,076 & $-0,085$ & 0,017 & $-0,170^{*}$ & 0,105 & $-0,208^{* * *}$ & $-0,023$ \\
\hline MSZP 2006/1998 & $-0,122$ & $-0,071$ & $-0,114$ & 0,052 & $-0,116$ & $-0,100$ & $-0,069$ & 0,032 & 0,154 \\
\hline SZDSZ 2006/1998 & 0,379 & 0,410 & $-0,228$ & $-0,033$ & $-0,164$ & 0,410 & $-0,301$ & 0,343 & $-0,087$ \\
\hline
\end{tabular}

Forrás: Saját számítás. 
Jankó Ferenc - Komornoki Mihály : Szuburbanizáció és választási földrajz:

Átalakuló pártválasztás Budapest térségében.

Tér és Társadalom 22. évf. 2008/4. 115-134. p.

Az így nyert komplex mutatókat ezután korreláltattuk a választási mutatók adatsoraival (10. táblázat). Elsőre kitünik, hogy a PCA4 és a FAKTOR2 egyik választási mutatóval sem mutat szorosabb kapcsolatot; fentebb láttuk, hogy a FAKTOR2-n épp azok a mutatók ülnek rajt nagy súllyal, amelyek a PCA4-et alkotják (EGYSZOB és ÉLETTCSAL). Másfelól viszont az együtthatók a többi fökomponens, illetve az első faktor és számos választási mutató között is közepes erősségü kapcsolatot jeleznek. Föképpen a szuburbán tereket jelző fökomponensek azok, amelyek jól és erős kapcsolattal jelzik a liberális párt területi szóródását, $s$ ugyanígy, negatív előjellel a FIDESZ és az FKGP területi tagolódására is utalnak.

Mindez a PCA1 területi tagolódását illusztráló 7. ábra, illetve az 5-6. ábra vizuális összevetésekor korántsem meglepö. E fökomponensnek a MIÉP 2002-es adatával is pozitív irányú a kapcsolata, azaz nem tévedett a korábbi klaszteranalízis, amikor a pozitív SZDSZ és MIÉP támogatottságú településeket egy típusba sorolta. A másik oldalról nézve jól kiviláglik az is, hogy a ruralitást, a demográfiai eróziót mutató főkomponensek elsősorban a FIDESZ és az FKGP pártjával mutatnak pozitív irányú, $s$ közepes erösségü korrelációt.

\section{7. ÁBRA}

A Pest megyei települések fökomponens értékei (PCA12)

(Principal Component Scores of Settlements in County Pest [PCA12])

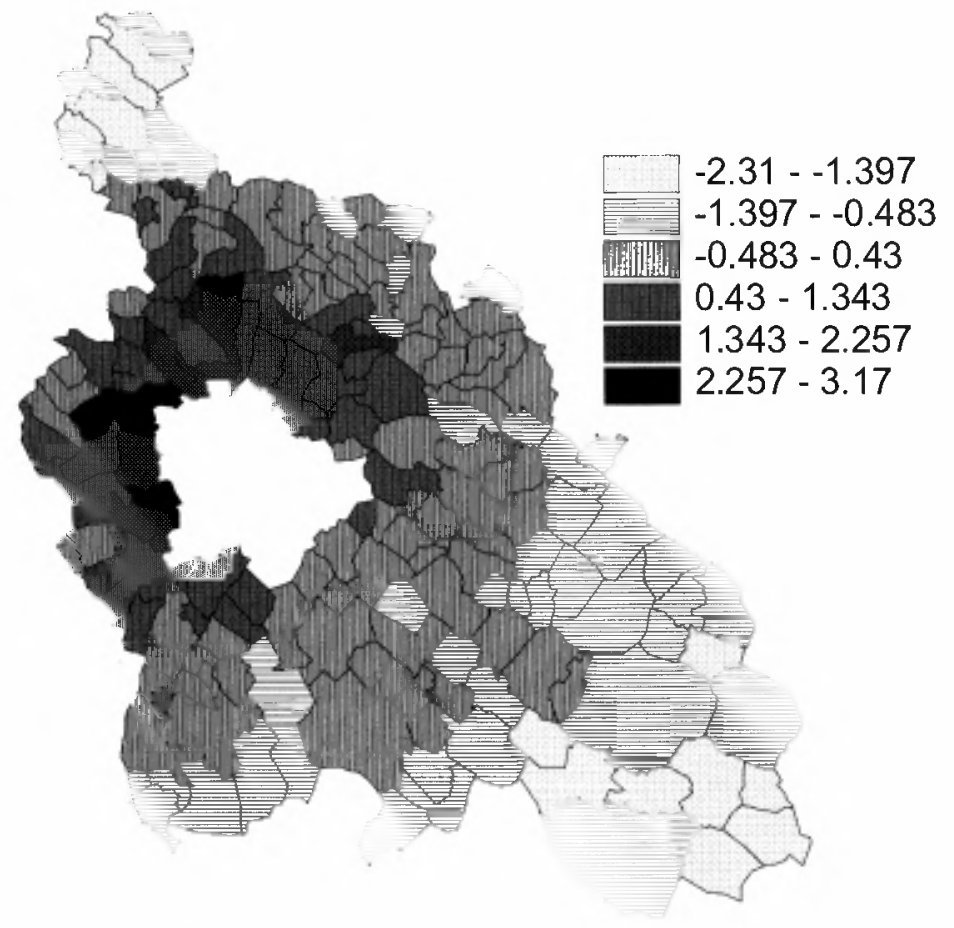

Forrás: Saját szerkesztés. 


\section{Összefoglalás}

Vizsgálataink Budapest térségében egyelöre tehát elvetik az egyes nyugati példákban látott központ-bal, szuburbia-jobb pártpreferencia-modellt, hiszen már az első fejezetben, a nagyobb aggregáltságú területi szintek vizsgálatakor ez látszott, ami aztán a települések politikai arculatának és dinamikájának tipizálásakor közvetetten, majd a szuburbanizáció fokát és a pártválasztást mérő mutatók sztochasztikus kapcsolatának kimutatásával közvetve is bizonyítást nyert. Az eltéró hazai fejlödés okát a következőkben látjuk: A magyarországi jobb és bal oldali pártok, s fóképp az SZDSZ, a nyugati demokráciák pártjaitól különbözö szavazóbázissal rendelkezik, ami a hazai párttörténelemben, a rövid, ám viharos rendszerváltás utáni időkben gyökeredzik. Másfelöl arra is utalást kaptunk, hogy a magyar szuburbanizációs folyamat erősen domináns jellegü, azaz jelenleg az egykori rurális terek, az agglomerációs települések erös átalakítása folyik, azaz a szuburbán zónákban nem érvényesül a szomszédsági hatás, hanem a kiköltözők a magukkal hozott politikai mintákat örzik meg. Lehetséges azonban, hogy e tendencia idővel átbillen, $\mathrm{s}$ a pártrendszer stabilizálódása, a pártideológiai paletta letisztulása esetén Magyarországon is kialakul a helyi társadalmak politikai szembenállása a központi város és környezete között.

\section{Jegyzetek}

${ }^{1}$ Kerepes és Kistarcsa adataiból Kerepestarcsát állitottunk elő, a Piliscsabából kivált Pilisjászfalu, a Nagykovácsiból önállósult Remeteszölős, és a Szödböl kivált Csörög adatát egyesítettük az anyatelepülésekével.

2 Az egységesség érdekében népszámlálási idöpont köré gyüjtöttük a többi adatot is, feltehetöleg a 2006-os választások idejére nem következett be markáns változás a települések társadalmi, gazdasági jellemzöiben, ill. a folyamatok irányában. Nem törekedtünk arra, hogy csak dinamikus mutatókat állítsunk elö, hiszen a pártválasztásban a jelen összetevỏk, azaz az urbanizáltsági állapot markáns szerepet játszik, nem csak a szuburbanizációs folyamat lefutása, dinamikája jelentös.

${ }^{3}$ Ezt a mutatót Walks (2005), ,ideológiai elhajlásnak" (ideological leaning) nevezte, s más logikával számolta ki: az egyes pártok eredményének adott területegységen belüli hányadosát osztotta az országos szint megfelelö hányadosával.

${ }^{4}$ Vö. Mészáros et al. (2007), akik tanulmányukban az országos választókerületek szintjén az 1994-es (MDF-KDNP-FKGP) blokk és a FIDESZ 2002-es és 2006-os struktúrája között nagyfokú összefüggést mutattak ki.

${ }^{5}$ A Lipset-Rokkan szerzőpáros 1967-es, alapmünek számító irása szerint négy centrum-periféria reláció határozza meg: domináns kultúra-szubkultúrák, szekularizáció-vallás, város-vidék és a tókésmunkásosztály közötti törésvonal.

\section{Irodalom}

Agnew, J.-Shin, M.-Bettoni, G. (2002) City versus metropolis: the Northern League in the Milan Metropolitan Area. - International Journal of Urban \& Regional Research. 2. 266-283. o.

Beluszky P. (1999) A budapesti agglomeráció kialakulása. - Barta Gy.-Beluszky P. (szerk.) Társadalmigazdasági átalakulás a budapesti agglomerációban. Regionális Kutatási Alapítvány, Budapest. 27-68. o.

Cox, K.R. (1968) Suburbia and voting behavior in the London metropolitan area. - Annals of the Association of American Geographers. 1. 111-127. o. 
De Maesschalck, F. (2004) The impact of electoral geography on urban politics: An underresearched theme in urban politics. Research and Training Network Urban Europe 9. 31. o. www.urbaneurope.net

De Maesschalck, F.-Loopmans, M. (2003) Electoral geography and manifestoes of new „urban” parties from 1977 to 1999: how urban are they really? - Belgeo. 3. 329-341. o.

Dövényi Z.-Kovács Z. (1999) A szuburbanizáció térbeni-társadalmi jellemzöi Budapest környékén. Földrajzi Értesitö. 1-2. 33-57. o.

Horváth B. (2004) A budapesti agglomerációs gyürủ népességváltozásának és társadalmi átrendezödésének hatása a politikai aktivitásra. - Falu-Város-Régió. 10.45-53. o.

Horváth B. (2005) A budapesti szuburbanizáció hatása az. Európai Parlament magyar tagjainak 2004. évi választására - esettanulmány. - Pap N. -Végh A. (szerk.) IV. Magyar Politikai Földrajzi Konferencia. A Kárpát-medence politikai földrajza. PTE TTK Földrajzi Intézet, Kelet-Mediterrán és Balkán Tanulmányok Központja, Pécs. 176-190. o.

Hubai L. (2001) Magyarország XX. századi választási atlasza, 1920-2000. Napvilág, Budapest.

Johnston, R--Jones, K--Sarker, R--Propper, C.-Burgess, S--Bolster, A. (2004) Party support and the neighbourhood effect: spatial polarisation of the British electorate. - Political Geography. 23. 367-402. o.

Johnston, R.J.-Pattie, C.J.--Dorling, D.F.L.-MacAlister, I.-Tunstall, H.-Rossiter, D.J. (2001) Social locations, spatial locations and voting at the 1997 British general election: evaluating the sources of Conservative support. - Political Geography. 20.85-111. o.

Karácsony G. (2006) Árkok és légvárak. A választói viselkedés stabilizálódása Magyarországon. - Karácsony G. (szerk.) Parlamenti választások 2006. DKMKA-BCE PTI, Budapest. 59-103. o.

Kovács R. (2007) A településszerkezet és a közigazgatási rendszer inkonzisztenciája - a szuburbanizáció példáján, Budapest térségében. - Buday-Sántha A.-Lux G. (szerk.) Évkönyv 2006. Pécsi Tudományegyetem Közgazdaság-tudományi Kara Regionális Politika és Gazdaságtan Doktori Iskola, Pécs. 287-310. o.

Kovács Z. (2000) Voksok a térben. A magyar parlamenti választások földrajzi jellemzöi. - Böhm A.-Gazsó F.-Stumpf I.-Szoboszlai Gy. (szerk.) Parlamenti választások. 1998. Politikai szociológiai körkép. 100-115. o.

Kovács, Z. (2001) The geography of post-communist parlamentary elections in Hungary. - Meusburger, P. Jöns, H. (eds.) Transformations in Hungary. Esseys in Economy and Society. Phisica-Verlag, Heidelberg-New York. 249-271. o.

Körösényi A. (1998) A magyar politikai rendszer. Osiris, Budapest. 70 94. o.

Lipset, S.M.--Rokkan, S. (1967) Party Systems and Voter Aligments: Cross National Perspectives. The Free Press, New York. 1-164. o.

Mészáros, J.-Solymosi, N.-Speiser, F. (2007) Spatial distribution of political parties in Hungary 1990 2006. - Political Geography. 26.804-823. o.

Perger É. (1999) Közigazgatási dilemmák. - Barta Gy.-Beluszky P. (szerk.) Társadalmi-gazdasági átalakulás a budapesti agglomerációban. Regionális Kutatási Alapítvány, Budapest. 181-223. o.

Szarvas L.-Tóth Cs. (2003) Pártok és pártrendszerek. - Gallai S.-Török G. (szerk.) Politika és politikatudomány. Aula, Budapest. 397-492. o.

Walks, R.A. (2004) Place of residence, party preferences, and political attitudes in Canadian cities. Journal of Urban Affairs. 3. 269-295. o.

Walks, R.A. (2005) City-suburban electoral polarisation in Great Britain, 1950-2001. - Transactions of the Institute of British Geographers. 30. 500-517. o.

Walks, R.A. (2006) The causes of city-suburban political polarisation? A Canadian case study. - Annals of the Association of American Geographers. 2. 390-414. o. 